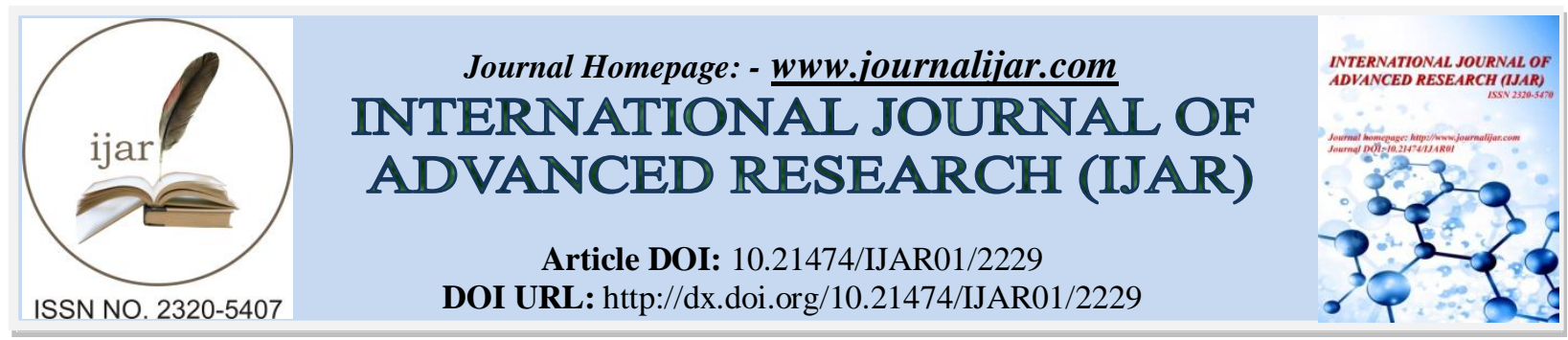

RESEARCH ARTICLE

\title{
CONSEQUENCES OF CULTURAL CHANGE IN PRE-COLONIAL India.
}

\author{
Anant Singh Jailyang. \\ J.R.F. Student (Sociology), 6-MIG, ADA Colony, Mumfordganj, Allahabad (U.P.), India.
}

\section{Manuscript Info}

Manuscript History

Received: 28 September 2016

Final Accepted: 30 October 2016

Published: November 2016

Key words:-

Consequences, Modernities, Cultural

Change. Colonial India,pre-colonial.

\begin{abstract}
Over the ages, unity of Indla has been symbolized by a cultural continuity, embodied Into a unified principle consciousness, which has contributed to the Identity of Its 'Inner-structure. This Inner structure primarily lies in the religious principles and their Interpretations. The unity or Identity has not been static. The cultural Innovations, which took place during pre-colonial era, symbolized the concept of Alternative modernities. This paper tries to define Alternative modernity's and its conquences of cultural change in pre-colonial period.
\end{abstract}

Copy Right, IJAR, 2016,. All rights reserved.

\section{Introduction:-}

On the contrary, the structure of this tradition, which throughout succeeded In projecting an Image of unity In valuestructures, ritual styles and systems of beliefs, also contributed to the growth of a unified world view of Indian civilization In spite of the fact that It contained Innumerable substrata of cultural beliefs and practices. Both its substantive structure and its underlying process have been diversified and pluralized, each flowing like small rivulets and streams in its own local and regional matrix and undergoing Its own localized convulsions. But each finally like all rivulets and streams, merged Into Great Ocean of the Indian cultural tradition. This Inter linkage of the processes in the little traditions of the Indian culture with its great tradition contributing to the processes of transformation and synthesis in latter is a historical reality.

There had been a continual change in the structure of tradition from its primordial- traditional moorings towards modernization. In the concept of modernization no evolutionary universalism is Implied. Modernization in its specific content and form is treated as a historical rather than a universal evolutionary reality. Modernization, as a from of cultural response. Involves attributes which are basically universalistic and evolutionary; they are panhumanistic, trans-ethnic and non-ideological. Modernization Is may be treated as kind of cultural-universal. Modernization symbolized by a rational attitude towards Issues and their evaluation from a universalistic and not pluralistic view point. Modernization is rooted to the scientific world view: It has deeper and positive association with levels of diffusion of scientific knowledge, technological skill and technological resources in a particular society. Modernity is not an exclusive possession of anyone ethnic cultural group but belongs to the humanity as a whole. Modernization process was not an exclusive peurview of imperialist power in India. The Pre-Colonial period witnessed major development in the field of religion, art, literature, poetry, music and philosophy. These changes and developments were emblematic of the advent of modernity to the Indian society. They suggest the much before the colonial Intervention, beginning with the 16th century the Indian society was heading towards modernity on its own and in due course of time it might have developed Its own indigenous version of modernity referred to as Alternative Modernities. The colonial intervention not only thwarted this process but changed its trajectory altogether. 
The rapid cultural Innovations which were rapidly taking place during pre-colonial period symbolized the concept of Alternative Modernities. Alternative Modernities holds that modernity always upholds within specific cultures or civilizations and that different starting points of transition to modernity lead to different outcomes. Alternative Modernities may emerge distinguished not just by marginal features, such food culture, style or political Ideals but by the central Institutions of technology and administration. Arguments for Alternative Modernity confirm the need for cultural theories of modernity - theories that foreground the place as well as time-but also lead Inevitably to tile concept of local agency. Alternative or non-western modernities emerge either by the development of hybridized culture or through the appropriation of transformation and adaptation which have been their characteristic features.

The applicability of the 'Unity in Diversity' motto to Pre-Colonial phase of Indian History is unique. Entire India was united culturally and spiritually, it remained united by the force of religion, philosophy and literature. Religion played a dominant role in effecting this unity and it was undergoing dynamic changes. The religious scene was fervent with creative activities and the era proved to be a fertile one with regard to religious literature. A Large number of renowned scholars and reformers emerged with the aim of freeing religious life from corrupt practice and superstitions.

The Mughal period was marked by two centuries of freedom from external invasions and enduring peace within empire. It enabled the Great Mughals to bring about political unification of India by the corporate activity of the nationalist forces. Beginning with Akbar, the Mughals strengthened the forces of national integration and solidarity through equitable treatment towards their subjects, religious toleration and the secular state policy. The Mughals played a premier role In effecting a healthy synthesis between the exotic Islamic tradition and ancient Indian cultural tradition thus bringing into existence a new social order, called the Indo-Islamic culture, which was neither Hindu nor Muslim but a synthetic culture of Pre-Colonial age.

The Bhakti Movement laid the seeds of modernity long time back. What Is particularly' remarkable is that most of the sects founded during Pre-Colonial period still have numerous followers and the school of Bhakti holds the field even today as dominant school of spiritual thought.

From this period up to the end of the medieval times, orthogenetic changes in the cultural Great traditions of Hinduism have mainly been marked by a growth of devotional- liberal traditions which had earlier started in the South. Guru Nanak in Punjab, Meera Bal in Rajasthan, Raman, Kablr, Tulsl Das in U.R, Chaitanya in Bengal, Dadu in Gujrat, Tukaram and Ramdas In Maharashtra emerged as the leading saints of the new devotional tradition in Hinduism. The contribution of these movements was two-fold; first, they liberated the orthodox conception of religious beliefs and carried to people in their own language, they rendered the so for esoteric ritual-hidden religious beliefs into simpler idioms of the masses; some of them, notably Kabir and Nanak also Introduced purely humanistic and mystical values in religious beliefs. Their second contribution was to bridge the gap between the little and Great traditions of Hindu culture, $\mathrm{m}$ fact, the devotional cults and the social structure of its movements as a major community channel for the continuity of Hindu Great tradition. An Important section of the saints like Ramananda, Kablr and Nanak were directly motivated by the need for introduction of more equalltarian and non-hierarchical value system in the world view of Hinduism.

Similarly, the emergence of the various schools of the Sufi thought was as much mark of creative resilience of Islam as Its synergetic and eclectic tendencies. Non-ritualism and abstract monotheism as preached by the Sufi saints and philosophers, was appealing to all sections of the community. Like wise, Buddhism and Jalnism emerged as protest movement against the Hindu caste-system, their growth led to formation of new cast like elementary groups which later degenerated into caste, contributing further to pluralistic traditions. These Movements had their impact on political and economic structures of the Indian society4. Jainism particularly was an urban movement, and both Jainism and Buddhism led to the Inerrancy of new mercantile cast In North India, of Bhakti Movements in North and South India. Of Arya samaj and Brahmo Samaj during the British regime, and finally the Gandhian movement in the contemporary society that culminated In India's political in dependence with partial exception of the Bhakti Movements in North India Which projected egalitarian values and sought for a synthesis between Hindu and Muslim traditions. All other movements were either breakaway processes to establish parallel Great tradition of Hinduism.

This probably shows the extent to which the social milieu appears decisive in shaping our sensibilities. The PreColonial India witnessed major developments In the field of art, literature, poetry, music and philosophy. The 
versatile genius of India furnished such excellent specimens of architecture, Painting, book craft, music, and literature that they command respect and admiration to this day and have won for India a place of pride in the cultural history oft the world.

Jahan-Ara was Interested In literary pursuits, while Aurangzeb's daughter Zeb-un-Nisha composed some poetry. In Pre-Colonlal period Le. Mughal period, special attention was paid to historiography. In the reign ofAkbar Abul Razal wrote Akbar-Namah and Ain-e-Akbarl which are unique In their character. Nowhere In Asia or Europe was such a work produced at that time. This was also an important period in the development of vernacular languages conjures regards. Reformers cropped up in every part of land and they expressed their teachings in the language of the people In order to make a direct appeal to their hearts. Urdu Language developed during this period. Somberly, Bengali language and literature also took great strides during this period. This was mainly the effect of religious reform movements; calligraphy was also in those days practiced as a fine art. The Pre-colonial period also witnessed rapid strides in painting. By thel6th century it had undergone such vital changes that it appeared In an altogether new style and its motifs became utterly foreign in the country. The painting of this period exercised considerable Influences over art of painting in Persia and central Asia. Under Jahangir, paintings reached its highest watermark. He himself was an excellent art critic.

The Pre-Colonial period witnessed great progress in the realm of architecture. Akbar evolved a new style of Indian architecture by utilizing the services of local talent drawn from different parts of the country. The mosques and tombs built in India have no family affinity to those in Persia and Turkey. This development In architecture was continued by his heirs.

Music also made great progress during this period. Especially during the reign of Akbar and Shahjahan, The great cultural activities which played Important role went parallel to political activities by giving Impetus to Alternative Modernities. We are heirs to the heritage of Jal Singh, Sah Wall Ullah, Dehlvl, Mir Taqi Mir, Mirza, Mohd. Ran Sauda, Khwaza Mir Dard, Mirza Ghalib etc. For their various contributions, this period was also instrumental in a Hindu-Muslim cultural synthesis. At the best one of the major achievements was the development of Urdu/Hind vi. Within a hundred years of Its arrival from the Deccan, Urdu/ Hind vl, flourished and reached Its zenith.

Akbar's talent for harmony and synthesies, Tulsi's regard for the social norms, Shivaji and Rana Pratap's love for liberty, Aurangzeb's trust in God, mercy and protection continued to inspire people to progress even today. The PreColonial period Indeed had ennobling elevating force. Further, the disintegration of the Mughal Empire In PreColonial period smoothened the way for the emergence of regional forces. These regional forces after establishing their political dominations, greatly added the promotion of regional centers that provided the ground for the religious and cultural efflorescence. The Mughal court culture that had been confined to the courts was to a certain extent disseminated. This was facilitated by the emergence of a variety of minor courts wherein arts flourished under the patronage of regional states. Also, it was more and more perceived by the people that such endeavour could in fact lead to social recognition.

Thus, these big regional units distinguished by the established local hierarchical had highly developed economies based upon regional markets, cultural and linguistic entities and strong sense of regional patriotism. The Independent states exhibited, within a rather short history of their existence, a variety of developmental models. An extremely Important integrative role was played by India's sacred geography or Pan-Indian network of pilgrimage places visited by the devotees from all regions. Many of these places were centers of art, culture and education where scholars, poets and students flocked from all parts of the sub-continent.

The Pre-Colonial period was witness to a significant flowering, efflorescence and general dissemination of religion and culture. The political domination was parallel accompanied with cultural outbursts. Great strides took place In the field of art, architecture, religion etc. Truly, Eogenia Vanina In her book 'Ideas and Society Sixteenth and Eighteenth Centuries' writes 'Compared to other countries of the Afro-Asian world, Pre-Colonial India did have something that enabled Its society albeit In Its elitist strata, to rather quickly accept the new Ideas. The Indian culture no doubt, has an Immense assimilative and resilient power. 15 The Pre-Colonial period was heading towards a framework of cultureless that made collaborations possible despite diversity Multiculturallsrn facilitates cooperation In face of diversities. The power of assimilation of Indian culture gave way for 'Globalization' which signifies the Inter- dependence of the Global and the local or the footedness of the Global In the local. The example 
"Think globally and act locally" is very significant. Myrdal thinks 'It Is not more difficult, but easier, to cause a big change happen rapldty than a small change gradually'.

The prime areas for such big rapid changes are social and Institutional conditions In the Indian society. These conditions hold keys for mobilization of all other conditions of development Similarly, Syed FaridAltas In his book 'Alternative Discourses In Asian Social Science: Responses to Eurocentrics' writes that 'the term alternative should not Indicate that Indigenous or local concepts should replace western ones, but there Is a need to think In universal terms for taking seriously non-western sources of Ideas and concepts in the social sciences and for considering a more critical assimilation of western theories and concepts. There is a general neglect of local literary and philosophical traditions which remain only objects of study and are not considered to the sources of concepts in social sciences.

India did Indeed witness a vibrant religious and cultural fervor. Great religions and cultural activities took place In consonance with political fervor giving way for Alternative Modernities. Indeed, the Pre- Colonial period left a rich and vital legacy of cultural or religious syncretism and this enriches the Indians with a valuable historical experience, which was required on the new stage of history.

\section{Reference:-}

1. Kurukshetra, Yojna New Delhi.

2. Singh, Yogendra, Modernization of Indian Tradition, Rawat Pub. Delhi, 2007. P 193.

3. Vanina Eugenia, An Article, India: The whole and Its parts to Historical Perspective, MR, ICHR, Delhi, Vol 35 Jan to Jul 2001 P. 104

4. Vantaa Eugenia, Ideas Society: India bet Sixteenth and Eighteenth Centuries, OVP, New Delhi, 2004 B6.

5. Singh, Yogendra, Cultural Change to India, Identity and Globalization, Rawat Publication Delhi, 2000, P.177

6. Vanina Eugenia, India and Society, Ibid. OD Cit. P. 213 